\title{
Commentary: The importance of being earnest and ... eclectic
}

\author{
Jean Bachet, MD, FEBCTS
}

\author{
$\overline{\text { From ADETEC }}$, Suresnes, France. \\ Disclosures: Author has nothing to disclose with regard to commercial support. \\ Received for publication Nov 5, 2018; accepted for publication Nov 5, 2018; available ahead of print Jan 8, 2019. \\ Address for reprints: Jean Bachet, MD, FEBCTS, ADETEC, Cardiovascular Research Financing, 1 Place Marcel \\ Legras, 92150, 92400 Suresnes, France (E-mail: jean.bachet@yahoo.fr). \\ J Thorac Cardiovasc Surg 2019;157:1322-3 \\ $0022-5223 / \$ 36.00$ \\ Copyright (c) 2018 by The American Association for Thoracic Surgery \\ https://doi.org/10.1016/j.jtcvs.2018.11.035
}

In the article titled "Late Outcomes of Strategic Arch Resection in Acute 1 Type A Aortic Dissection" published in this issue of the Journal, Yang and co-workers ${ }^{1}$ analyze the results of 2 large cohorts of patients who underwent hemi-arch or total aortic arch replacement for acute type A dissection during the past 2 decades.

The authors have appropriately compared the preoperative, intraoperative, and postoperative conditions, factors of complications, and results in both groups. Through this analysis, the authors came to the conclusion that "Both hemi-arch and aggressive arch replacement are appropriate approaches for select patients with ATAAD."

Their data obviously support the conclusion, and the proposed eclectic choice of surgery according to the patients' anatomic or pathologic condition seems appropriate.

Such a study, as well as several other recent or contemporary studies, outlines and confirms the evolution of the surgical treatment of acute type A dissection during the last 2 decades. Most patients in developed countries worldwide presently undergo operation during emergency procedures, implying more extended aortic replacement than in the past, with the aid of open distal anastomosis and circulatory arrest during the distal repair, with antegrade selective cerebral perfusion at some degree of core hypothermia and in many instances of total arch replacement the use of the elephant trunk or frozen elephant trunk techniques.

This is obviously what has been used in the presently reported experience. And when looking at the obtained results, we may observe that those techniques were efficacious and safe because the outcomes in both groups were satisfactory and, more important, similar in terms of hospital and long-term mortality, as well as in rates of reoperations. Nevertheless, some points could be questioned.

The authors indicate that a group of 41 patients who underwent a resection of the distal aorta between the innominate and the left carotid arteries and a reimplantation

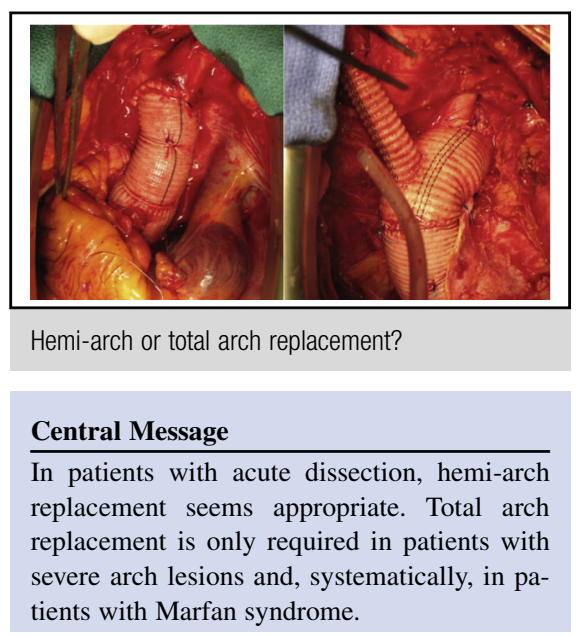

See Article page 1313 .

of the innominate artery in the ascending aortic prosthesis were not included in the study. Why? After all, such resections and replacements can be considered as a sort of "hemi-arch replacement" or, at least, "partial arch replacement." Could the results in this group modify the whole statistics?

Another matter of controversy could be the notion of "surgeon experienced in aortic (or dissection) surgery." As far as we know, experience in such matters (as in any other technical matters) is obtained through repeated cases, and all experienced surgeons have been inexperienced ones and yet had to perform acute dissections procedures to become knowledgeable in this field. In addition, most departments of surgery cannot afford to have several surgeons perfectly trained and experienced in aortic surgery and, moreover, in acute dissection repair.

Therefore, it is somewhat surprising that, despite the statement that, in the reported experience, "All ATAAD cases were primarily performed by three aortic surgeons who do 15-25 ATAAD cases/year,' 16 patients with Marfan syndrome underwent only a hemi-arch replacement, whereas only 5 had a total arch replacement. This seems in contradiction with the modern tendency in dealing with those patients. Indeed, in terms of risk and late outcome, we have to deal with 2 very different groups of patients: those without and those with genetic connective tissue disorders. In this latter group and contrary to the results reported in the present article, we may observe through the literature ${ }^{2,3}$ a large difference in the rate of distal aneurysmal evolution and 
late reoperations in patients in whom the total arch was not replaced. This was the case in the article by Schoenhoff and colleagues ${ }^{4}$ on the one hand and the article by our group ${ }^{5}$ on the other hand, in which the rates of patients with Marfan syndrome requiring a second or even third reoperation for total arch replacement were $33 \%$ and $73 \%$, respectively.

Some years ago, in an editorial commentary about Schoenhoff and colleagues' article, ${ }^{4}$ we wrote, “... Because of the major risk of reoperation, systematic potentially curative total replacement of the aortic arch appears to be a logical option in patients presenting with acute type A dissection in order to reduce the number of re-operative procedures in these generally young patients, who already pay a high toll to their disease." 6

We have not changed our opinion since then.

\section{References}

1. Yang B, Norton EL, Shih T, Farhat L, Wu X, Hornsby WE, et al. Late outcomes of strategic arch resection in acute type A aortic dissection. $J$ Thorac Cardiovasc Surg. 2019;157:1313-21.e2

2. Geirsson A, Bavaria JE, Swarr D, Keane MG, Woo YJ, Szeto WY, et al. Fate of the residual distal and proximal aorta after acute type A dissection repair using a contemporary surgical reconstruction algorithm. Ann Thorac Surg. 2007;84: 1955-64.

3. Fattouch K, Sampognaro R, Navarra E, Caruso M, Pisano C, Coppola G, et al Long-term results after repair of type A acute aortic dissection according to false lumen patency. Ann Thorac Surg. 2009;88:1244-50.

4. Schoenhoff F, Kadner A, Czerny M, Jungi S, Meszaros K, Schmidli J, et al. Should aortic arch replacement be performed during initial surgery for aortic root aneurysm in patients with Marfan syndrome? Eur J Cardiothorac Surg. 2013; 44:346-51.

5. Bachet J, Larrazet F, Goudot B, Dreyfus G, Folliguet T, Laborde F, et al. When should the aortic arch be replaced in Marfan patients? Ann Thorac Surg. 2007; 83:S774-9.

6. Bachet J. Editorial comment: total aortic arch replacement in Marfan patients caution or boldness? Eur J Cardiothorac Surg. 2013;44:351-2.

Access to The Journal of Thoracic and Cardiovascular Surgery Online is reserved for print subscribers!

Full-text access to The Journal of Thoracic and Cardiovascular Surgery Online is available for all print subscribers. To activate your individual online subscription, please visit The Journal of Thoracic and Cardiovascular Surgery Online, point your browser to http://www.mosby.com/jtcvs, follow the prompts to activate your online access, and follow the instructions. To activate your account, you will need your subscriber account number, which you can find on your mailing label (note: the number of digits in your subscriber account number varies from 6 to 10 ). See the example below in which the subscriber account number has been circled:

\section{Sample mailing label}

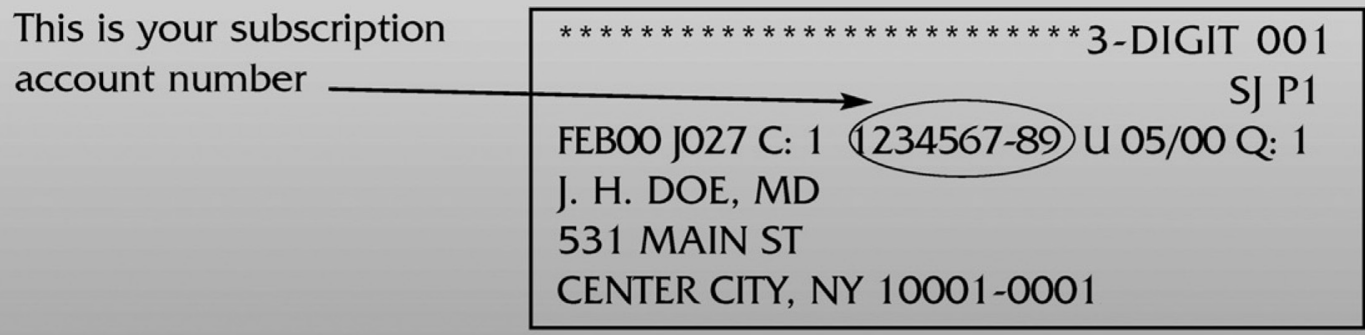

Personal subscriptions to The Joumal of Thoracic and Cardiovascular Surgery Online are for individual use only and may not be transferred. Use of The Journal of Thoracic and Cardiovascular Surgery Online is subject to agreement to the terms and conditions as indicated online. 